\title{
EDITORIAL
}

\section{Impact of COVID-19 Virus Pandemic on Surgical Practices: rejuvenation}

As with other branches of medical services, surgical services has been greatly suffered, shortened, scheduled and adapt a safer approach. Many of the surgical patient suffered not only due to virus contamination but also late initiation, lower approach and life saving versus long await conflicts. We never stopped emergency surgical procedures at any cost and also continue services by means of online consultation.

The impact of COVID-19 on surgical practice is widespread, ranging from work force and staffing issues, adaptation of safe surgery at the same time risk reduction to health care providers, especially those directly involve in operation theatre. In Bangladesh and South east Asia, we have to continue most of the surgical services since the first day of lockdown. We remain open in most of the centers to cover the emergency patients and malignant cases. Even we remain open in all our academic activities for the students, trainees and post-graduate students. We organized so many national and international workshops, seminars, symposium through webinars. Our learners oriented quickly on online classes. Even we also organize some assessment through online as well.

From the experience of some hospitals in Wuhan, surgeons are at high risk of infection. Healthcare workers must take preventive measures for personal safety in strict accordance with the epidemic assessment level. Due to the limited supply of personal protective equipment (PPE) in many centers, their use should be the restricted by patient to patient. Healthcare workers shall strictly follow the donning and doffing of personal protective gear. ${ }^{1}$

Vascular surgeons in the United States report, substantiated impact on their practices during the COVID-19 pandemic. Vascular surgeons also reported that about half of the office bound laboratories were closed due to lack of manpower. Call schedule modification were common and patient of critical limb ischaemia gets focal attention. ${ }^{2}$

Our daily activities now boost up due to current slowness of infectivity rate. Even after getting full dose of vaccination our surgeons started performing all sorts of surgery as normal schedule. The first COVID-19 case in south Africa was reported on 5 March 2020, and the nation declared a national state of disaster from 18 March 2020. As part of COVID-19 disaster planning, many hospitals nationwide reduced routine in patient services to free up hospital beds and healthcare workers. Surgical services which includes operative treatment of elective and emergency conditions are hospital based and may include the need for intensive care unit transfer especially post operatively. It has been observed in African countries that COVID-19 patient mostly cared in Govt. hospital than private hospitals. ${ }^{3}$

(J Bangladesh Coll Phys Surg 2021; 39: 211) DOI: https://doi.org/10.3329/jbcps.v39i4.55940

Professor Abul Bashar Md. Jamal

Councillor \& AMP; Honorary Director (RTM), BCPS

and Professor \& AMP; Head, Dept. of Surgery

Dhaka Medical College, Dhaka.

\section{References:}

1. Bar D, Alam ABMK, Rahman AZMM, Suzana N. COVID19 Recommendations of optimum patient management and surgical Safety. J Bangladesh Coll Phys Surg2020; 38 : 116-121.

2. Monawad NJ, WOOK, Malgor RD, Coogan SM, Sheahan MG, Shalhub S. The impact of COVID-19 pandemic on vascular Surgery practice in the United States. J vas Surg2020; 73( 3): 772-779.

3. Chu KM, Smith M, Dteyn E, Goldberg P, Bougard H, Buccimazzu . Changes in surgical practices in 85 South African Hospitals during COVID-19 hard lockdown. S Afr Med J. 2020; 110 (9): 916-919. 
